\title{
MODEL PEMBELAJARAN SPRM BERBASIS VISUALISASI ASSEMBLING UNTUK MENINGKATKAN KOMPETENSI PRAKTIK LABORATORIUM
}

\author{
Harjanti $^{1}$, Hermanu Joebagio ${ }^{2}$, Ambar Mundigdo ${ }^{3}$ \\ Magister Kedokteran Keluarga Program PASCASARJANA UNS
}

\begin{abstract}
ABSTRAK
Berdasarkan hasil observasi yang dilakukan ternyata banyak peserta didik yang tidak mampu atau kesulitan dalam menyelesaikam kasus dan melakukan praktik dari kasus yang diberikan, padahal pada saat responsi lancar dalam menjawab pertanyaan yang dilontarkan Dosen. Selain itu pada saat diterjurkan ke lahan untuk Praktik lapangan (PL) peserta didik mengalami kebingungan. Hal ini disebabkan karena tidak adanya demonstrasi dan ilustrasi tentang pengelolaan rekam medik secara umum di Rumah Sakit. Maka perlu adanya perubahan tentang model pembelajaran di laboratorium yaitu dengan adanya visualisasi. Penelitian ini bertujuan Mengetahui pembelajaran SPRM saat ini, Mengetahui prosedur pengembangan model pembelajaran berbasis visualisasi assembling, Mengetahui efektifitas model pembelajaran yang dikembangkan dalam pembelajaran di laboratorium.
\end{abstract}

Metode penelitian pengembangan/Research \& Development (R\&D). Prosedur penelitian pengembangan yaitu pra pengembangan model, pengembangan model dan evaluasi model. Uji coba produk yaitu validasi ahli materi dan ahli media, uji coba peserta didik meliputi uji coba satu-satu dan uji coba kelompok kecil yang terdiri dari 10 anak. Jenis data yaitu data kuantitatif dan data kualitatif. Sumber data ahli materi, ahli media, peserta didik. Tehnik pengumpulan data dengan cara wawancara, kuesioner dan tehnik tes. Instrumen pengumpulan data yaitu pedoman wawancara, kuesioner dan tes. Tehnik analisis data adalah analisis data kondisi awal, analisis data kelayakan produk menggunakan konversi skala 5 dan analisis efektifitas produk menggunakan independent t-test.

Pembelajaran SPRM di laboratorium APIKES Mitra Husada Karanganyar antar Dosen tidak sama. Ada yang pakai demonstrasi ada yang tidak. Skor validasi ahli materi 4,6 kategori sangat baik, validasi ahli media 4,57 kategori sangat baik, uji coba satu-satu 4,78 kategori baik, uji coba kelompok kecil 3,98 kategori baik dengan kesimpulan layak diproduksi dengan revisi. Uji efektifitas nilai signifikasi 0,000 sehingga Ho ditolak. Ada perbedaan rata-rata signifikasi antara kelompok yang diberi tidak diberi visualisasi dan yang diberi visualisasi.

Kata kunci: Metode Pengembangan, SPRM, Visualisasi

\section{PENDAHULUAN}

Sistem Pengelolaan Rekam Medik (SPRM) merupakan salah satu mata kuliah kompetensi seorang perekam medis. Adapun kompetensi dasar yang harus dicapai dalam mata kuliah SPRM meliputi Pencatatan data rekam medis di Tempat Pendaftaran Rawat Jalan (TPPRJ), Penyelenggaraan rekam medis di bagian pelayanan medis di Unit Rawat Jalan (URJ), pencatatan data rekam medis di Tempat Pendaftaran Pasien Gawat Darurat (TPPGD) dan Unit Gawat Darurat (UGD), Pencatatan data rekam medis di Tempat Pendaftaran Pasien Rawat Inap (TPPRI), Penyelenggaraan rekam medis di bagian pelayanan medis di Unit Rawat Inap (URI),
Penyelenggaraan rekam medis di bagian pelayanan medis di Instalasi Pemeriksaan Penunjang (IPP), Pengelolaan rekam medis di bagian Assembling, Koding Indeksing, Analising Reporting dan Filing.

SPRM memiliki beban 4 SKS, 2 SKS berupa teori di kelas sedangkan 2 SKS dilakukan praktik di Laboratorium. Akademi Perekam Medis dan Informatika Kesehatan (APIKES) Mitra Husada untuk pembelajaran teori di kelas diampu oleh 2 dosen mata kuliah sedangkan untuk pembelajaran praktik di laboratorium dibagi menjadi 4 kelompok yang diampu oleh 8 dosen dengan setiap kelompok 1 dosen dan 1 asisten dosen. 
Kegiatan praktikum ditujukan untuk membantu keberhasilan peserta didik dalam mencapai kompetensi yang diharapkan. Praktikum di laboratorium APIKES Mitra Husada dilaksanakan setelah materi di kelas selesai, dalam pembelajaran praktik di laboratorium dilakukan melalui 4 tahap yaitu responsi, penyelesaian kasus, praktik sesuai kasus dan pembuatan laporan.

Responsi dilakukan dengan maksud untuk mengukur seberapa paham peserta didik memahami materi yang disampaikan oleh Dosen ketika di kelas, hal ini dilakukan sebagai syarat apakah peserta didik boleh mengikuti praktik atau tidak. Jika peserta didik tersebut tidak bisa menyelesaikan soal yang diberikan maka akan diulang-ulang sampai bisa baru boleh mengikuti praktik.

Setelah responsi selesai maka siswa akan diberi kasus sesuai dengan teori yang disampaikan, setiap peserta didik akan mendapatkan kasus yang berbedabeda sehingga penyelesaikannya juga akan berbeda. Jika kasus yang diberikan sudah selesai maka dari kasus tersebut dipraktikkan dan diakhir praktik ada pembuatan laporan yang dikumpulkan.

Berdasarkan hasil observasi yang dilakukan ternyata banyak peserta didik yang tidak mampu atau kesulitan dalam menyelesaikan kasus dan melakukan praktik dari kasus yang diberikan, padahal pada saat responsi lancar dalam menjawab pertanyaan yang dilontarkan Dosen. Selain itu pada saat diterjurkan ke lahan untuk Praktik lapangan (PL) peserta didik mengalami kebingungan. Materi yang sering membuat peserta didik mengalami kesulitan untuk praktik adalah pada materi Assembling.

Assembling merupakan salah satu bagian unit rekam medis yang mempunyai tugas pokok (1) merakit kembali Dokumen Rekam Medik (DRM) rawat jalan, rawat inap menjadi urut atau runtut sesuai dengan kronologi penyakit yang bersangkutan (2) meneliti kelengkapan data yang seharusnya tercatat di dalam formulir rekam medis sesuai dengan kasus penyakitnya (3) meniliti kebenaran pencatatan data rekam medis sesuai dengan kasus penyakitnya (4) mengendalikan DRM yang dikembalikan ke unit pencatat data karena isinya tidak lengkap (5) mengendalikan penggunaan nomor rekam medis (6) mendistribusikan dan mengendalikan penggunaan formulir rekam medis (Shofari, 2004).

Berdasarkan uraian diatas maka perlu ada suatu inovasi tentang model pembelajaran yang diterapkan pada saat praktikum SPRM. Dengan adanya inovasi tersebut diharapkan peserta didik lebih antusias dalam mengikuti praktik, peserta didik mampu mempraktikkan kasus dengan mudah dan ketika praktik di lahan juga lebih memahami dan siap karena mata kuliah SPRM adalah salah satu mata kuliah kompetensi bagi seorang perekam medis. Selain itu juga membantu Dosen mendemonstrasikan kegiatan pengelolaan rekam medik sesuai teori.

Model pembelajaran dapat didefinisikan sebagai kerangka konseptual yang digunakan sebagai pedoman dalam melakukan pembelajaran. Dengan demikian, model pembelajaran merupakan kerangka konseptual yang melukiskan prosedur yang sistematis dalam mengorganisasikan pengalaman belajar untuk mencapai tujuan menurut Joyce\&Weil (dalam Santyasa, 2007)

Adapun usulan untuk model pembelajaran yang ditawarkan adalah menggunakan model pembelajaran kontekstual dengan visualisasi tentang pengelolaan rekam medik dari salah satu Rumah Sakit yang sudah menjalankan sistem pengelolaan rekam medik dengan benar sesuai dengan standar dari DepKes. Visualisasi merupakan penyampaian suatu informasi dengan menggunakan video ataupun gambar.

Dengan adanya visualisasi tentang pengelolaan rekam medik dapat digunakan sebagai pengganti kegiatan demonstrasi yang seharusnya dilakukan oleh dosen sebelum praktik dilaksanakan.

Jadi untuk kegiatan praktik laboratorium setelah responsi dilakukan maka dilanjutkan dengan pemutaran video sesuai dengan materi setelah itu baru dilakukan praktik sesuai dengan materi yang diberikan, penyelesaian kasus, praktik dan pembuatan laporan.

Dari latar belakang diatas maka peneliti mengusulkan adanya penelitian dengan judul "Model Pembelajaran SPRM Berbasis Visualiasasi Assembling untuk Meningkatkan Kompetensi Praktik Laboratorium"

\section{METODE PENELITIAN}

Metode penelitian yang dipergunakan adalah metode penelitian dan pengembangan atau Research \& Development (R\&D).

Produk yang dihasilkan dari penelitian dan pengembangan ini adalah visualisasi kegiatan 
pengelolaan rekam medik unit assembling, dengan adanya visualisai ini diharapkan mampu membantu dosen pengampu praktikum dalam hal mendemonstrasikan materi yang akan dipraktikkan. Visualisasi ini juga diharapkan peserta didik lebih mudah dalam menyelesaikan dan mempraktikkannya sehingga dapat meningkatkan kompetensi praktik laboratorium.

Metode yang digunakan dalam penelitian ini meliputi metode deskriptif untuk menghimpun kondisi yang ada di lapangan. Sedangkan metode evaluatif dipergunakan untuk mengevaluasi keefektifan kelayakan bahan ajar dan proses pengembangan. Dengan adanya evaluasi maka dapat diperoleh masukan tentang kekurangan dari produk yang dibuat sehingga dapat dilakukan revisi sebelum dilaksanakan uji efektifitas.

\section{Tabel 1 Tahapan Pengembangan Model}

\begin{tabular}{|c|c|c|}
\hline Tahap & Langkah & Aktifitas \\
\hline \multirow{3}{*}{$\begin{array}{l}\text { Pra } \\
\text { pengembangan } \\
\text { model }\end{array}$} & \multirow{3}{*}{1} & 1. Identifikasi masalah \\
\hline & & 2. Analisa kebutuhan \\
\hline & & 3. Perancangan model \\
\hline \multirow{6}{*}{$\begin{array}{l}\text { Pengembangan } \\
\text { model }\end{array}$} & \multirow{6}{*}{2} & $\begin{array}{l}\text { 1. Memilih RS yang } \\
\text { akan digunakan } \\
\text { dalam pembuatan } \\
\text { visualisasi }\end{array}$ \\
\hline & & $\begin{array}{l}\text { 2. Prosedur kerja yang } \\
\text { akan dibutuhkan } \\
\text { untuk visualisai }\end{array}$ \\
\hline & & $\begin{array}{l}\text { 3. Membuat visualisasi } \\
\text { kegiatan Assembling } \\
\text { di RS }\end{array}$ \\
\hline & & $\begin{array}{l}\text { 4. Kajian model } \\
\text { pembelajaran kepada } \\
\text { ahli materi, media } \\
\text { dan peserta didik }\end{array}$ \\
\hline & & 5. Perbaikan/ Revisi \\
\hline & & 6. Produk akhir \\
\hline Evaluasi Model & 3 & $\begin{array}{l}\text { Penilaian efektifitas } \\
\text { model pembelajaran } \\
\text { dengan menggunakan uji } \\
\text { independent } t \text {-test }\end{array}$ \\
\hline
\end{tabular}

Pelaksanaan uji coba produk penelitian dilakukan di APIKES Mitra Husada Karanganyar, sebagai bahan evaluasi awal penerapan model pembelajaran SPRM sebelum diterapkan di pembelajaran laboratorium. Uji coba produk dilakukan oleh ahli materi, ahli media dan perwakilan dari peserta didik. Adapun tahapan tersebut adalah sebagai berikut:
1. Validasi ahli materi dan ahli media

2. Uji coba peserta didik

Prosedur uji coba peserta didik adalah:

a. Uji coba dilakukan dengan uji coba satu-satu, kemudian dilakukan uji coba kelompok kecil dengan jumlah peserta didik 10 orang.

b. Menjelaskan kepada peserta didik bahwa adanya pengembangan model pembelajaran berbasis visualisasi agar membantu mereka dalam menyelesaikan kasus

c. Menjelaskan bahwa peserta didik bebas mengemukakan pendapat terkait dengan kelebihan dan kekurangan dari visualisai yang telah dibuat

d. Menampilkan visualisasi yang telah dibuat

e. Membagikan lembar kuesioner tentang tanggapan peserta didik terhadap visualisasi yang sudah ditampilkan

f. Menganalisis informasi dan temuantemuan yang terkumpul

g. Melakukan revisi berdasarkan data dan informasi yang diperoleh

Data yang dikumpulkan dalam penelitian pengembangan ini terdiri dari dua jenis, yaitu data kualitatif dan data kuantitatif. Masing-masing adalah sebagai berikut :

\section{Data kualitatif}

Data kualitatif adalah data yang berbentuk kata-kata, data diperoleh dari penelitian awal tentang pelaksanaan proses pembelajaran SPRM dalam praktik materi assembling di laboratorium. diperoleh dengan cara observasi dan wawancara.

\section{Data kuantitatif}

Data kuantitatif diperoleh dari peserta didik. Data kuantitatif dipergunakan untuk menilai keefektifitas bahan ajar yang dikembangkan.

Sumber data dalam penelitian pengembangan model pembelajaran berbasis visualisasi ini dikelompokkan menjadi dua sumber data, yaitu sumber data awal penelitian dan sumber data dalam uji efektifitas. Sumber data tersebut meliputi: Ahli materi, Ahli media dan Peserta didik.

Adapun teknik pengumpulan data adalah wawancara, kuesioner dan tehnik tes berupa kasus.

Instrumen yang dipergunakan dalam pengumpulan data pada penelitian ini meliputi pedoman wawancara, kuesioner dan tes berupa kasus. 
Teknik analisis data yang dilakukan meliputi sebagai berikut :

a. Analisis data kondisi awal

b. Analisis data kelayakan produk

Dalam angket disediakan lima pilihan jawaban untuk memberikan tanggapan tentang kualitas produk yang dikembangkan yaitu:

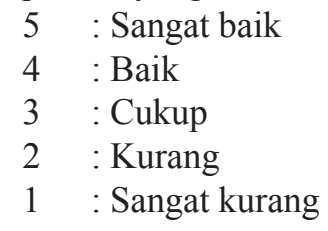

Tabel 2 Konversi data kuantitatif ke data kualitatif dengan skala 5

\begin{tabular}{|c|l|l|}
\hline Nilai & \multicolumn{1}{|c|}{ Skor } & \multicolumn{1}{|c|}{ Kriteria } \\
\hline $\mathrm{A}$ & $\mathrm{X} \geq \mathrm{Xi} 1,8 \mathrm{Sbi}$ & Sangat baik \\
\hline $\mathrm{B}$ & $\begin{array}{l}\mathrm{Xi}+0,6 \mathrm{Sbi}<\mathrm{X} \leq \mathrm{Xi}+ \\
1,8 \mathrm{Sbi}\end{array}$ & Baik \\
\hline $\mathrm{C}$ & $\begin{array}{l}\mathrm{Xi}-0,6 \mathrm{Sbi}<\mathrm{X} \leq \mathrm{Xi}+ \\
0,6 \mathrm{Sbi}\end{array}$ & Cukup \\
\hline $\mathrm{D}$ & $\begin{array}{l}\mathrm{Xi}-1,8 \mathrm{Sbi}<\mathrm{X} \leq \mathrm{Xi} \\
-0,6 \mathrm{Sbi}\end{array}$ & Kurang \\
\hline $\mathrm{E}$ & $\mathrm{X} \leq \mathrm{Xi}-1,8 \mathrm{Sbi}$ & Sangat kurang \\
\hline
\end{tabular}

Sumber: Miyarso, 2009

Keterangan:

Rerata skor ideal (Xi) : 1/2 (skor maksimal ideal + skor minimal ideal)

Simpangan baku skor ideal (Sbi) : 1/6 (skor maksimal ideal - skor minimal ideal)

X Ideal : skor impiris

Dalam penelitian ini dikatakan produk layak jika hasil penilaian dari ahli materi, ahli media dan peserta didik minimal nilai $\mathrm{C}$ dengan kategori cukup.

Untuk menghitung skor rata-rata dari penilaian antara ahli media, ahli materi dan peserta didik yang tealh dikembangkan maka menggunakan rumus:

\begin{tabular}{|l|}
\hline $\mathrm{X}=\sum \mathrm{X} / \mathrm{N}$ \\
Keterangan: \\
$\mathrm{X} \quad$ : Skor rata-rata \\
$\sum \mathrm{X}:$ Jumlah skor \\
$\mathrm{N} \quad$ : Jumlah butir pernyataan \\
\hline
\end{tabular}

Kemudian skor yang diperoleh di konversikan menjadi data kualitatif skala lima.

Berdasarkan rumus tersebut untuk mengubah data kuantitatif menjadi kualitatif menggunakan pedoman sebagai berikut:
Skor maksimal ideal $=5$

Skor minimal ideal $=1$

Tabel 3 Panduan konversi data kuantitatif ke data kualitatif dengan skala 5

\begin{tabular}{|c|l|l|}
\hline Nilai & \multicolumn{1}{|c|}{ Skor } & \multicolumn{1}{|c|}{ Kriteria } \\
\hline A & $\mathrm{X}>4,21$ & Sangat baik \\
\hline B & $3,40<X \leq 4,21$ & Baik \\
\hline C & $2,60<X \leq 3,40$ & Cukup \\
\hline D & $1,79<X \leq 2,60$ & Kurang \\
\hline E & $X \leq 1,79$ & Sangat kurang \\
\hline & & \\
\hline
\end{tabular}

Sumber: Miyarso, 2009

\section{c. Analisis data efektifitas}

Data yang akan diuji diperoleh dari hasil pengerjaan kasus tentang assembling oleh peserta didik. Peserta didik sejumlah akan dibagi menjadi 2 kelompok, yaitu sebagai kelompok kontrol dan sebagai kelompok eksperimen.

Data dianalisis menggunakan SPPS dengan menggunakan rumus independent t-tes.

Selanjutnya hasil $t$ hitung dibandingkan dengan $\mathrm{t}$ tabel, tabel $\mathrm{t}$ yang digunakan dengan derajat bebas $(\mathrm{df}=\mathrm{db}=\mathrm{dk})=\mathrm{n}-1$. Apabila thitung $>$ t tabel, maka Ho ditolak, dan menerima Ha. Artinya ada beda secara signifikan antara rata-rata kelompok kontrol dengan kelompok eksperimen (Riwidikdo, 2009).

\section{HASIL DAN PEMBAHASAN}

\section{Hasil}

\section{Deskripsi Pembelajaran SPRM}

1. Lokasi Penelitian

Penelitian dilakukan di dua lokasi yaitu Rumah Sakit PKU Muhammadiyah Karanganyar yang digunakan untuk pengambilan data berupa visualisasi dan Akademi Perekam Medis dan Informatika Kesehatan (APIKES) Mitra Husada Karanganyar yang digunakan untuk uji coba produk dan uji efektivitas dari produk yang diterapkan.

2. Deskripsi Pembelajaran SPRM di Laboratorium

1) Persepsi mahasiswa terhadap proses pembelajaran

Berikut adalah hasil kutipan wawancara tentang kesan mahasiswa terhadap proses pembelajaran: 
“.....Kalau dari pembelajarannya itu.. ya...kadang...ya..tegantung suasana sih bu...kalau ngepasi materinya itu dipegang apa..dhelalah gampang ya menyenangkan tapi kalau materi...apa namanya susah ya..tidak menyenangkan..." (Mahasiswa 1)

“......Sistem pembelajarannya sudah enak, tidak terlalu cepat, ada tanya jawab satu per satu..jadi tau dimana letak kesalahanya..."(Mahasiswa 2) “......Kalau apa..menjelaskan enak... tapi kadang terlalu cepat...pokoknya gini...pokoknya gini....jadinya rancu.. kadang yang diresponsi Cuma barisan depan saja..tidak semua diresponsi...." (Mahasiswa 3)

2) Persepsi mahasiswa terhadap media pembelajaran

Berikut adalah kutipan hasil wawancara tentang persepsi mahasiswa terhadap media pembelajaran:

“ ....Kalau untuk formulirnya sendiri itu yo sudah lumayan lengkap... tetapikan kalau kita Rekam Medik dan Informatika Kesehatan...disesuaikan sama informatikanya...punya kita kayaknya jadi rancu..." (Mahasiswa 1) “....Jauh beda sama di sana...kayak filing...duh beda jauh sama yang ada di sini..." (Mahasiswa 2)

“....Kurang kayaknya..sudah lamalama formulirnya...padahal sekarang sudah komputerisasi...."(Mahasiswa 3)

3) Persepsi mahasiswa terhadap kompetensi Dosen SPRM

Berikut adalah hasil kutipan wawancara tentang persepsi mahasiswa terhadap kompetensi Dosen SPRM:

“......Kalau dari Dosennya sendiri enak bu neranginnya...kompetensinya mencukupi...dari dosennya enak dpraktekkan....ini cara ngisinya...kurang waktu dan kurang tenaga tapi gak tau.... "(Mahasiswa 1)

“.....Kompetensi Dosen yang di lab... sudah mencukupi tapi kalau yang di kelas belum..."(Mahasiswa 2)

“ ....Sudah...kalau jelasinnya jelas.... prakteknya satu per satu jadi pada paham...." (Mahasiswa 3)
4) Minat Mahasiswa terhadap pembelajaran SPRM

Berikut adalah hasil kutipan wawancara tentang minat mahasiswa terhadap pembelajaran SPRM:

“......Seneng sih...karena berguna banget buat praktek...yang ada diteori emang benar-benar ada semua...Cuma penggunaan yang masih belum diterapkan di Rumah Sakit..." (Mahasiswa 1)

“.....Minat...lebih memilih praktek daripada di kelas karena saya suka belajar...sistem ada tanya jawab suka...mengetes sejauh mana kita tau materi..." (Mahasiswa 2)

“.....Minat ke materi... tapi prakteknya kurang....( Mahasiswa 3)

5) Persepsi mahasiswa terhadap metode pembelajaran SPRM

Berikut adalah hasil kutipan wawancara tentang metode pembelajaran di laboratorium:

“.....Kalau sistemnya dipisah...responsi hari sendiri....praktek hari sendiri...jadi nanti $1 \mathrm{x}$ responsi $2 \mathrm{x}$ materi...misalnya hari ini responsi 1 materi, besok responsi 2 materi prakteknya langsung, dikumpulkan 2 responsi itu. Jadi kadang Dosennya sendiri, yang penting sudah ngelakuin prakteknya....kalau demonstrasinya ngedemoinnya enak aja sih, ketika prakteknya masih bingung...apa namanya yang dikenalin cuma kelompok pertama, kalau datang kelompok terakhir tidak dikenalin....jadinya gak semua pegang...harusnya ngerakit tapi tidak, 1 dapat ngerakit, 1 dapat neliti kelengkapan...prosesnya masuk 2..2..kelompok tengah-tengah yang ngajari teman..." (Mahasiswa 1)

“.....Demonstrasi ada 1 untuk 1 kelas, baru responsi...teori...praktek kayak di Rumah Sakit...biasanya gini.. anak-anaknya paham...tapi gitu bu rame karena bercanda...misal kasus selesai ditanya satu-satu...kasus..dikasih satu-satu trus praktek lagi yang banyak teori...." (Mahasiswa 3)

“....menyelesaikan kasus banyak kendala bahkan ada mahasiswa yang tidak tau sama sekali...jadi butuh 
demosntrasi soalnya Dosennya sendiriyang di kelas terlalu cepat..." (Mahasiswa 2)

6) Persepsi mahasiswa terhadap peningkatan kompetensi SPRM

Berikut adalah hasil kutipan wawancara tentang persepsi mahasiswa terhadap upaya peningkatan kompetensi SPRM:

“......Mungkin adakan tambahan kayak kuliah perdana dibahas semua materi lagi dari awal sampai tengah semester.. dibahas lagi mana kekurangan, dipilah-pilah..kalau dari Dosen udah enak, ditambah lagi pengajarnya.. sehingga semua dapat tidak cuma kelompok awal...kelengkapan formulir, masih kekur kelengkapan disesuaikan sama standarisasi RS..." (Mahasiswa 1)

“....Jam praktek ditambah...ada demonstrasi sebelum praktik...diagnosa yang digunakan yang umum karena mahasiswa bingung seperti singkatan-singkatan CRF...adanya sistem komputerisasi..." (Mahasiswa 2)

“....Mungkin media ditambah komputer..jadi sama dengan RS karena RS sudah komputerisasi..ditambah Dosen..formulirnya..buku ekspedisi kalau satu nunggunya lama...." (Mahasiswa 3)

3. Deskripsi Pembelajaran SPRM dari Dosen di Laboratorium

1) Latar belakang Dosen/ profil Dosen Berikut adalah kutipan wawancara dengan Dosen yang bersangkutan tentangblatar belakang atau profil dosen:

“.....E..mulai di MH februari 2005... terus ngajarnya SPRM...iya di laboratorium 2005...latar belakang pendidikan D3 Rekam Medik...terus S1... sekarang S2...trus..e..mengajar sudah 7 tahun masuk tahun ke 8...yang dulu mahasiswanya sedikit sampai mahasiswanya banyak..."

2) Kemampun dosen dalam memanfaatkan dan mengkreasikan media pembelajaran
Berikut adalah kutipan wawancara dengan dosen berkaitan dengan media pembelajaran:

“....Biasanya didemokan dikenalkan bahan-bahannya dulu..kalau misal assembling...formulir-formulir sesungguhnya ditunjukkan dulu kepada mereka..kalau di kelas hanya ditunjukkan in saja...apa presentasi PP aja... kalau dilaboratorium kita sudah bisa menunjukkan barangnya seperti apa.. cara ngisinya bagaimana...."

3) Metode pembelajaran SPRM

Tahapan pertama yaitu dilakukan dengan responsi. Berikut kutipan wawancaranya:

“.....Tahapan pertahapan responsi... responsi lebih menekankan pada materi...apa namanya...ada proses tanya jawab....harapannya mahasiswa di lab tau dulu materinya apa saja...SOPnya seperti apa...buku, catatan dan dokumennya apa saja di bagian itu atau materi yang sedang dipraktekkan..."

"...Mahasiswa akan diberikan kasus, dalam menyelesaikan kasus biasanya didemokan, dikenalkan bahan-bahannya...Kasusnya secara tertulis untuk kemudian kita cek untuk penyelesaian kasusnya..Kita contohkan satu contoh kasus..karena mahasiswa akan menerima kasus yang berbeda..jadi kita contoh kasus memperhatikan... menyelesaikan.."

“....untuk kemudian mempraktekkan sesuai panduan kita...dalam arti ada proses pembenaran...mereka mempraktekkan kasus..baru...satu persatu kita cek, tidak efektif butuh waktu lama...."

4) Sistem evaluasi pembelajaran SPRM Berikut kutipan wawancara tentang sistem evaluasi SPRM:

“.....Wawancara kepada mereka kalau mata kuliah SPRM saling berkaitan...contoh assembling, koding indeksing...kita harus bisa memastikan bahwa mereka memahami materi tersebut..selain itu mahasiswa harus membuat laporan dari parktik itu... biasanya dari laporan juga akan terpantau paham atau belum...tes praktik akhir semester pasti ada..biasanya 
disetiap ujian...tidak hanya ujian tulis tapi ada ujian praktik, tidak harus mempraktikkan semua materi tapi secara undian, bisa dapat koding, assembling dan lain-lain, mereka harus siap semua materi..."

\section{Prosedur Pengembangan Model Pembelaja-} ran Visualisasi Assembling

Pengembangan model pembelajaran dilakukan dengan cara demonstrasi yang dilakukan dengan cara manual, diganti dengan pemutaran visualisasi dengan durasi 15-20 menit, untuk materi assembling yang dibuat dengan durasi 17 menit 48 detik. Visualisasi tersebut berupa video yaitu gabungan antara teks, gambar bergerak, animasi, efek dan audio.

Adapun isi dari visualisasi assembling yang dibuat yaitu:

a. Merakit kembali Dokumen Rekam Medik (DRM) menjadi urut atau runtut sesuai dengan kronologi penyakit yang bersangkutan

b. Meneliti kelengkapan data yang seharusnya tercatat di dalam formulir rekam medis

c. Mengendalikan penggunaan formulir rekam medis

d. Alur dokumen rekam medik yang lengkap dan tidak lengkap

Berikut adalah hasil validasi ahli materi dan ahli media:

a. Validasi Ahli Materi dan Ahli Media

1) Ahli materi

Adapun hasil validasi dari ahli materi yaitu 4,6 masuk dalam kategori sangat baik.

Berikut adalah komentar dan saran umum dari ahli materi:

a) Penambahan materi tentang perakitan dokumen baru dibuat perkasus (narasi)

b) Penekanan materi assembling yaitu pada perakitan dokumen baru (kata kunci: surat persetujuan rawat inap dan surat perintah rawat inap) dan perakitan dokumen setelah dipakai (RM 1: Ringkasan masuk dan keluar), dokumen siap simpan.

c) Penekanan pada batas waktu kelengkapan pengisian dokumen rekam medik dan pengembalian dokumen rekam medik dari bangsal ke bagian assembling (narasi) d) Penambahan pengisian kartu kendali menggunakan format dari Departemen Kesehatan (DepKes), sedangkan yang ditempel pada dokumen yang tidak lengkap adalah lembar ketidaklengkapan

e) Slide buku dan catatan dibuat satu persatu agar terbaca dan terlihat

f) Slide ke 2 (kompetensi dan indikator) diperlambat agar terbaca dan terlihat

g) Durasiwaktukuranglebih 15 menit

h) Dokumen yang dikembalikan ke bangsal/ bagian koding harus sudah di map

2) Ahli media

Adapun hasil validasi dari ahli materi yaitu 4,57 masuk dalam kategori sangat baik.

Berikut adalah komentar dan saran umum dari ahli media:

a) Pada tampilan standar kompetensi, kompetensi dasar dan indikator diperpanjang durasinya

b) Pada tampilan selalu ada audio

c) Gambar di ruangan diterangkan

d) Narasi diperbaiki

b. Uji Coba Peserta Didik

1) Uji coba satu-satu

Adapun hasil uji coba satu-satu yaitu 4,75 masuk dalam kategori sangat baik.

Berikut adalah komentar dan saran umum dari peserta didik:

a) Lebih diperjelas lagi dalam pengisian audio atau dubbing

b) Pada slide materi, pemberian soal atau contoh soal, perhitungan IMR/ DMR dalam menampilkan videonya diperlambat 2-3 detik.

2) Uji coba satu-satu

Adapun hasil uji coba satu-satu yaitu 3,98 masuk dalam kategori baik.

Berikut adalah komentar dan saran umum dari peserta didik:

a) Komposisi dan warna sedikit mencolok sehingga warnanya lebih baik diterangkan atau sedikit dicerahkan 
b) Tulisan penjelasan tentang IMR dan DMR diperjelas

3. Efektifitas Model Pembelajaran yang Dikembangkan Dalam Pembelajaran di Laboratorium

Untuk mengetahui efektifitas visualisasi yang telah dbuat, maka dari 60 mahasiswa dibagi menjadi 2 kelompok yang satu diberi perlakuan dengan metode lama dan kelompok yang lain menggunakan metode baru.

Hasil pengerjaan kasus dengan menggunakan model pembelajaran yang lama, dimana dalam pengerjaan kasus pada hasil perhitungan tidak ada satuan, buku, catatan dan dokumen yang digunakan untuk praktik tidak disebutkan contohnya buku ekspedisi, lembar kekurangan dokumen RM dll, alur dokumen rekam medik tidak disebutkan secara lengkap. Sedangkan hasil pengerjaan kasus dengan menggunakan motode baru menggunakan visualiasasi, dimana untuk hasil perhitungan lengkap dengan satuan, alur dokumen rekam medik ditulis secara urut dan lengkap serta buku, catatan dan dokumen yang digunakan juga disertakan sesuai dengan penggunaannya.

Berdasarkan nilai yang diperoleh dari hasil pengerjaan kasus maka diuji menggunakan uji statistik independent t-tes untuk mengetahui keefektian dari visualisasi yang dibuat. Sebelum dilakukan uji efektifitas maka data dilakukan uji normalitas data, diketahui bahwa nilai $Z$ hitung adalah 1, 230. Sedangkan nilai signifikasi (Asymp. Sig) besarnya 0, 97 dibandingkan dengan $\alpha=0,05$, sehingga signifikasi $(p>0,05)$ dengan demikian Ho diterima yang artinya data berdistribusi normal.

Setelah diketahui data merupakan data berdistribusi normal, maka dari data tersebut dilakukan uji efektifitas menggunakan uji statistik independent t-test. nilai t hitung sebesar $-7,674$, sedangkan nilai signifikasinya adalah 0,000 hal ini menunjukkan Ho ditolak yang artinya ada perbedaan rata-rata signifikasi antara mahasiswa yang menggunakan visualisasi dan yang tidak menggunakan visualisai dalam menyelesaikan kasus.

\section{PEMBAHASAN}

\section{Deskripsi Pembelajaran SPRM}

Pelaksanaan pembelajaran SPRM di laboratorium APIKES Mitra Husada Karanganyar dimulai dengan adanya responsi. Menurut Brown and Atkins (1988 pertanyaan atau daftar pengecekan evaluasi diri atau di APIKES Mitra Husada Karanganyar disebut dengan responsi ini adalah salah satu upaya yang dapat dilakukan untuk meningkatkan kompetensi praktik di laboratorium, karena peserta didik dipaksa untuk dan berfikir tentang semua aspek aktivitas di laboratorium. Responsi yang dilakukan di APIKES Mitra Husada Karanganyar yaitu dengan memberikan pertanyaan kepada peserta didik satu per satu, pertanyaan yang diberikan sesuai dengan materi yang disampaikan dosen ketika perkuliahan di kelas.

Setelah selesai responsi ada Dosen yang melakukan review materi, ada yang demostrasi dengan membagi menjadi menjadi beberapa kelompok kecil namun ada juga yang tidak melakukan demonstrasi. Hal ini dilakukan karena kegiatan demonstrasi ini memakan waktu yang banyak yaitu 20-30 menit, padahal untuk praktik hanya 100 menit. Sehingga alokasi waktu untuk pengerjaan kasus dan praktik juga kurang, tidak jarang praktik laboratorium yang dilakukan melebihi jam raktik yang ditentukan yaitu 3-4 jam padahal waktu praktik 1 jam 40 menit.

Demonstrasi yang selama ini dilakukan juga kurang efektif karena tidak semua mahasiswa mendapatkan demonstrasi, sehingga mahasiswa juga mengalami kesulitan ketika mengerjakan kasus yang dampaknya menghambat praktik yang akan dilakukan karena dosen harus mengulang kembali demonstrasi yang telah dilakukan kepada setiap mahasiswa. Selain itu demonstrasi yang dilakukan juga tidak memberikan gambaran yang nyata di lahan praktik ataupun Rumah Sakit sehingga ketika mereka melakukan praktik di lapangan juga merasa canggung.

Sarana dan prasarana yang ada di laboratorium kurang memadai dan tidak disesuaikan dengan perkembangan, hal ini juga akan menghambat proses praktikum karena mahasiswa harus bergantian dalam menggunakan sarana dan prasarana yang ada serta Dosen dalam menggunakan sarana dan prasarana untuk demostrasi. Adanya perbedaan sarana dan prasarana yang ada di laboratorium juga akan menghambat mahasiswa ketika praktik di lahan.

Pada dasarnya demonstrasi sangat membantu mahasiswa dalam mengerjakan kasus dan memberikan gambaran tentang praktik yang dilakukan karena demonstrasi akan memberikan ilustrasi materi dan dilakukan setelah perkuliahan. 
Setelah demonstrasi atau review yang dilakukan oleh Dosen dilanjutkan dengan pengerjaan kasus. Setiap anak akan mendapatkan kasus yang berbeda. Kasus merupakan suatu contoh masalah yang ada di Rumah Sakit atau suatu contoh kejadian yang ada di Rumah Sakit berkaitan dengan pengelolaan DRM. Dalam pengerjaan kasus mahasiswa harus mengerjakan kasus secara urut sesuai dengan prosedur pengelolaan rekam medik disetiap unit rekam medik dan setiap prosedur yang dituliskan juga harus sarana dan prasarana yang akan digunakan dalam praktik.

Kasus yang telah diselesaikan akan dikoreksi oleh dosen pengampu mata kuliah, jika sudah benar maka langsung dilanjutkan dengan praktik namun jika ada prosedur yang masih kliru ataupun ada prasarana yang digunakan belum disebutkan maka harus dibenarkan dulu sampi benar baru dilanjutkan praktik.

Mahasiswa yang telah melaksanakan praktik maka harus membuat laporan dari praktik yang telah dilakukan di buku folio bergaris. Hasil laporan ini digunakan sebagai evaluasi, laporan akan dikoreksi oleh dosen yang meliputi dasar teori, kasus, hasil pengerjaan kasus, kesimpulan, daftar pustaka dan pengesahan.

Sedangkan evaluasi di tengah semester dan akhir semester dilakukan dengan memberikan kasus kepada setiap mahasiswa secara acak. Setelah pengerjaan kasus selesai, maka mahasiswa mempraktikkan kasus tersebut. Maka mahasiswa harus mempelajari semua materi karena kasus yang diberikan secara acak.

Namun dari hasil evaluasi yang dilakukan dapat diketahui bahwa model pembelajaran yang diterapkan belum bisa mendapatkan hasil yang maksimal, hal itu dapat diketahui dari hasil pengerjaan kasus oleh mahasiswa. Bahkan ada mahasiswa yang sama sekali tidak tau kasus tersebut harus diapakan. Maka disarankan adanya perubahan model pembelajaran yang diterapkan, yaitu model pembelajaran kontekstual yaitu suatu proses pembelajaran yang mengkaitkan antara materi pembelajaran dengan kehidupan sehari-hari sehingga mahasiswa mampu membuat hubungan antara pengetahuan dalam kehidupan nyata (Trianto, 2007).

Kehidupan nyata yang dimaksud pada pembelajaran yang dimaksud adalah mengkaitkan materi yang diajarkan dengan dunia kerja. Sehingga mahasiswa sendiri dipersiapkan lebih awal untuk mengenal dunia kerja, ketika praktik lapanganpun mereka tidak akan merasa canggung atau kesulitan.

Adapun cara pengkaitan materi dengan dunia kerja dilakukan dengan cara, demonstrasi yang biasanya dilakukan dengan manual atau yang biasa dilakukan diganti dengan cara memfasilitasi mahasiswa berupa visualisasi yang diputar menggunakan komputer ataupun laptop.

Seperti menurut Brown and Atkins (1988) salah satu cara peningkatan pembelajaran di laboratorium yaitu dengan cara memfasilitasi mahasiswa. Pembelajaran di laboratorium sedapat mungkin dapat membuat mahasiswa belajar secara mandiri dan saling belajar dengan temannya.

Fasilitas tersebut berupa visualisasi tentang pengelolaan Rekam Medik di Rumah Sakit berupa video yang isinya tentang pengenalan buku, catatan dan dokumen yang digunakan, video tentang prosedur pengelolaan DRM, materi serta contoh kasus dan pengerjaannya.

Visualisasi tersebut berdurasi sekitar 15-20 menit, dengan adanya visualisasi ini diharapkan mahasiswa tahu tentang gambaran alur dokumen rekam medik di Rumah Sakit dan cara pengerjaan kasus. Dosen juga terbantu karena tidak perlu menjelaskan ulang materi atau sebagai pengganti demonstrasi serta menghemat alokasi waktu.

Dengan adanya visualisasi juga dapat digunakan untuk belajar di rumah karena bisa dicopy menggunakan flasdisk dan dapat diputar ulang menggunakan laptop, komputer ataupun tablet.

\section{Prosedur Pengembangan Model Pengembangan Visualisasi Assembling}

Tahapan pembuatan visualisasi dimulai dengan mengidentifikasi masalah yang dialami mahasiswa ketika praktik di laboratorium. Hasil identifikasi menunjukkan bahwa mahasiswa mengalami kesulitan ketika mengerjakan kasus dan mengalami kebingungan ketika praktik di lahan/ Rumah Sakit. Maka dilakukan pengembangan yaitu mengganti demonstrasi yang dilakukan dengan pemutaran visualisasi yang telah dibuat.

Sebelum pembuatan visualisasi yang pertama dilakukan adalah memilih Rumah Sakit yang digunakan sebagai tempat pengambilan gambar dan unit yang dipilih. Pada uji coba yang dipilih adalah 
Rumah Sakit PKU Muhammadiyah Karanganyar dengan unit bagian assembling.

Setelah tempat dipilih maka dilakukan pengambilan gambar yaitu tentang catatan, buku, formulir yang digunakan, prosedur pengendalian formulir rekam medik, prosedur dokumen rekam medik di bagian assembling.

Gambar yang sudah diambil maka digabung menjadi satu untuk dibuat menjadi video. Dalam video tersebut berisi tentang kompetensi dasar, profil rumah sakit, buku catatan dan dokumen yang digunakan, prosedur pengendalian formulir rekam medik dan contoh susunan dokumen rekam medik untuk kasus anak, prosedur dokumen rekam medik di bagian assembling, materi incomplete medical record (IMR) dan delique medical record (DMR), contoh kasus, contoh soal dan cara penyelesaian.

Menurut Heinich (dalam Pribadi dan Putri 2001) video termasuk media yang diproyeksikan. Video menampilkan unsur gambar (visual) dan suara (audio) secara bersamaan sehingga mampu mengungkapkan obyek atau peristiwa secara sesungguhnya. Dengan perancanaan yang baik maka akan membuat proses komunikasi (pembelajaran) menjadi efektif.

Visualisasi yang berupa video tersebut divalidasi ke ahli materi yaitu Tri Lestari, SKM. Hasil validasi dari ahli materi dapat diperoleh skor 4,6 maka termasuk dalam kategori sangat baik karena nilai $X>4,21$. Kesimpulan dari hasil validasi yaitu layak namun ada beberapa hal yang harus direvisi. Hasil revisi tidak semua dapat dilakukan yaitu tentang dokumen yang dikembalikan diberi map dokumen rekam medik, hal ini tidak dapat dilakukan karena di Rumah Sakit yang berkaitan untuk berkas yang dikembalikan ke bangsal tidak dimap.

Selain divalidasi ahli materi maka divalidasi ke ahli media yaitu Dr. Nunuk Suryani, M. Pd, skor dari ahli media yaitu 4,57 maka masuk kategori sangat baik karena nilai $X>4,21$. Kesimpulan dari hasil validasi ahli media yaitu layak diproduksi dengan revisi.

Setelah selesai direvisi maka tahap selanjutnya dilakukan uji kelayakan ke salah satu mahasiswa yang telah menempuh praktik SPRM. Uji coba dilakukan dengan menjelaskan dahulu kepada mahasiswa tersebut tentang pengembangan yang dibuat, setelah itu video diputarkan dan mahasiswa diminta untuk memberikan penilaian dan saran terhadap visualisasi yang telah dibuat. Skor dari hasil uji satu-satu yaitu 4,75 maka termasuk pada kategori sangat baik karena nilai $X>4,21$. Kesimpulan dari hasil penilaian uji satu-satu layak untuk diproduksi namun ada beberapa yang harus direvisi.

Langkah selanjutnya yang dilakukan yaitu setelah revisi dari uji coba satu-satu dilakukan maka dilakukan uji coba kelompok kecil. Produk yang telah dibuat diuji kesepuluh anak. Prosedur yang dilakukan sama dengan uji coba satu-satu, adapun skor yang diperoleh adalah 3,98 masuk dalam kategori baik karena nilai $\mathrm{X}$ berada diantara nilai 3,40-4,21. Kesimpulan layak untuk diproduksi namun masih ada beberapa hal yang harus direvisi.

Masukan atau hal-hal yang harus direvisi pada uji coba kelompok kecil tidak semua direvisi dan disajikan pada hasil penilaian. Hal ini dikarenakan ada beberapa saran yang menyimpang atau tidak berkaitan dengan materi assembling. Sebagai contoh ketikan lembar masuk dan keluar lebih baik ditulisa tangan daripada diketik karena tidak teratur dengan yang ditepatkan. Hal itu tidak mungkin direvisi karena selain tidak berkaitan dengan materi juga merupakan kebijakan dari Rumah Sakit yang bersangkutan.

Selain itu ada yang memberikan saran untuk pengambilan gambar seharusnya lebih diperjelas pada poin-poinnya, misalkan pada gambar lembar resume pulang seharusnya pada tulisan lembar resume ikut diambil dan diperjelas untuk bukti bahwa lembar tersebut benar-benar lembar resume pulang, sebagian gambar sudah jelas. Hal ini tidak bisa dilakukan karena dokumen rekam medis itu rahasia maka isi dari dokumen rekam medis harus dijaga kerahasiaanya. Jika hal itu dilakukan maka termasuk melanggar kode etik perekam medis karena telah menyebar luaskan isi dokumen rekam medis pasien. Contoh yang lain bisa dilihat dari lampiran.

Menyimpangnya saran yang diberikan oleh mahasiswa dikarena mahasiswa bingung tentang apa yang harus mereka sampaikan, namun produk masih dapat dilanjutkan untuk revisi dikarena skor yang diperoleh masuk kategori baik dengan nilai B karena produk layak diproduksi minimal adalah mendapatkan nilai $\mathrm{C}$.

Saran dari uji coba kelompok kecil direvisi, setelah selesai revisi maka burning di CD dan siap untuk dilakukan uji efektifitas. 


\section{Efektifitas Model Pembelajaran yang Dikem- bangkan Dalam Pembelajaran di Laboratorium}

Visualisasi yang telah selesai dilakukan uji coba kelompok kecil dan telah direvisi, maka tahap berikutnya dilakukan uji efektifitas yang dilakukan terhadap 60 mahasiswa yang dibagi menjadi 2 kelompok yaitu kelompok kontrol dan kelompok eksperimen.

Kelompok kontrol terdiri dari 30 anak dari kelas A semester III (Tiga) APIKES Mitra Husada Karanganyar. Uji efektifitas dilakukan dengan cara mengumpulkan mahasiswa, selanjutnya dilakukan sesi tanya jawab secara lisan dan review materi yang berkaitan dengan assembling. Selanjutnya anak-anak diberi kasus yang berkaitan dengan materi assembling untuk dikerjakan.

Sedangkan kelompok eksperimen terdiri dari 30 anak dari kelas B semester III (Tiga) APIKES Mitra Husada Karanganyar. Uji efektifitas dilakukan dengan cara mengumpulkan mahasiswa, selanjutnya dilakukan sesi tanya jawab dan pemutaran video tentang materi assembling. Setelah selesai anakanak diberi kasus materi assembling yang sama seperti kelompok kontrol untuk dikerjakan.

Hasil pengerjaan kelompok kontrol dan ekperimen dikoreksi dan dibandingkan. Dari hasil pengerjaan 2 kelompok tersebut dapat diketahui bahwa hasil pengerjaan kelompok eksperimen lebih lengkap karena menyertakan buku, catatan dan dokumen yang digunakan serta prosedur setiap langkah detail disebutkan.

Nilai hasil pengerjaan diuji menggunakan kolmogrov sminrov untuk mengetahui normalitas data menggunakan spss 15 , hasilnya data normal dengan nilai t hitung 0,97 . Selanjutnya diuji efektifitas menggunakan independent t-test dengan hasil signifikasi 0,000 yang berarti ada perbedaan antara kelompok kontrol dan kelompok eksperimen.

Berdasarkan hasil uji efektifitas maka diharapkan untuk pembelajar di laboratorium diganti menggunakan model pembelajaran konstektual berbasis visualisasi. Mahasiswa lebih merasa senang dengan adanya video sebelum dilakukan pengerjaan kasus, selain mempermudah pemahaman materi, juga dapat memberikan gambaran tentang pelaksanaan assembling di Rumah Sakit serta dapat mempersingkat waktu. Dengan adanya video juga membantu dosen untuk melaksanakan demonstrasi, jadi dosen tidak perlu mengulang lagi kesetiap anak dan semua anak dapat menyaksikan demonstrasi.

Menurut Witara (2010) manfaat adanaya media pembelajaran ini adalah penyampaian materi pembelajaran dapat diseragamkan, proses pembelajaran menjadi lebih jelas dan menarik, proses pembelajaran menjadi lebih interaktif, efisiensi dalam waktu dan tenaga, meningkatkan kualitas hasil belajar siswa, media memungkinkan proses belajar dapat dilakukan di mana dan kapan saja, media dapat menumbuhkan sikap positif siswa terhadap proses belajar, mengubah peran guru ke arah yang lebih positif dan produktif.

\section{PENUTUP}

\section{Simpulan}

Penelitian yang dilakukan adalah jenis penelitian pengembangan. Adapun tujuan penelitian ini adalah untuk meningkatkan kompetensi praktik mahasiswa pada mata kuliah Sistem Pengelolaan Rekam Medik (SPRM) di APIKES Mitra Husada Karanganyar.

Berdasarkan hasil penelitian maka dapat diambil kesimpulan:

\section{Pembelajaran SPRM}

Pembelajaran SPRM di laboratorium APIKES Mitra Husada Karanganyar masih banyak kekurangan yaitu ada beberapa dosen yang tidak menggunakan demonstrasi, sehingga mahasiswa kesulitan untuk menyelesaikan kasus dan praktik.

Walaupun ada dosen yang melakukan demonstrasi namun masih terdapat kekurangan yaitu tidak semua mahasiswa dapat mengikuti demonstrasi dikarenakan sistem demonstrasinya hanya dilakukan pada mahasiswa yang berada dikelompok awal, sedangkan kelompok yang pertengahan atau sampai akhir tidak mengetahui demonstrasi yang dilakukan.

Proses demonstrasi yang seperti itu juga menghabiskan waktu yang banyak sekitar 20-30 menit, padahal alokasi waktu untuk praktik 100 menit dan setelah demonstrasi masih pengerjaan kasus dan praktik satu per satu mahasiswa. Selain itu demonstrasi tidak memberikan gambaran tentang pengelolaan RM di Rumah Sakit.

Maka pada penelitian ini disarankan untuk adanya perubahan model pembelajaran yaitu model pembelajaran kontekstual 


\section{Prosedur pengembangan}

Pertama dilakukan yaitu memilih Rumah Sakit yang digunakan untuk contoh pengelolaan Dokumen Rekam Medik, selanjutnya dilakukan pengambilan data yang berupa gambar dan video, setelah itu digabung dengan teks, narasi, instrument diberi efek untuk digabung menjadi video. Setelah video selesai maka divalidasi ke ahli media dengan skor 4,57 kesimpulan layak diproduksi dengan revisi, ahli materi skor 4,6 kesimpulan layak diproduksi dengan revisi, setelah direvisi dilakukan uji coba satu satu dengn skor 4,75 dengan kesimpulan layak diproduksi dengan revisi, selanjutnya setelah direvisi maka dilakukan uji coba kelompok kecil dengan 10 orang dengan skor rata-rata 3,98 dengan kesimpulan layak diproduksi dengan revisi.

\section{Efektifitas model pembelajaran}

Pembelajaran di laboratorium dilakukan dengan menguji visualisasi tersebut ke 60 anak yang di bagi menjadi 2 kelompok yaitu yang diputarkan video dan hanya direview materi. Berdasarkan hasil uji independent t-test diketahui nilai 0,000 yang berarti Ho ditolak yang artinya ada perbedaan rata-rata signifikasi antara mahasiswa yang menggunakan visualisasi dan yang tidak menggunakan visualisai dalam menyelesaikan kasus.

\section{DAFTAR PUSTAKA}

Arsyad, A. 2002. Media Pembelajaran, edisi 1. Jakarta: PT. Raja Grafindo Persada

Angkowo, R \& Kosasih, A. 2007. Optimalisasi Media Pembelajaran. Jakarta: PT. Grasindo

Azwar, S. 2011. Tes Prestasi: Fungsi Pengembangan Pengukuran Prestasi Belajar: Yogyakarta: Pustaka Belajar

Brown and Atkins. 1988. Effective Teaching in Higher Education. London: Mathuen

Borg, W. R\& Gall, M, D. 1983. Education Research: An Introduction, Fourth Edition. New York: Longman

Depdiknas. 2002. Pendekatan Kontekstual dalam Pembelajaran. Jakarta: Depdiknas
2003. Pendekatan Kontekstual. Jakarta: Dirjen Dikti Direktorat Pembinaan Tenaga Kependidikan dan Ketenagaan Perguruan Tinggi

Depkes RI. 2006. Pedoman Penyelenggaraan \& Prosedur Rekam Medik Rumah Sakit. Jakarta: Direktorat Jendral Bina Pelayanan Medik

Joko, Y. S. 2004. Sumber Belajar Anak Cerdas. Jakarta: Grasindo

Januszewski, A \& Molenda, M. 2008. Educational Technology. New York: Lawrance Erlbaum Associates

Jacobsen, et all. 2009. Metode-metode pengajaran. Jakarta: Pustaka Pelajar.

Kardi, S dan Nur, M. 2000. Pengajaran Langsung. Surabaya: Unesa: University Press

Nurhadi, Y. B\& Senduk, A. G. 2004. Pembelajaran Kontekstual (Contextual Teaching and Learning/ CTL) dan Penerapannya dalam $K B K$. Malang: UM Press

Pribadi, B. A\& Putri, D. P. 2001. Media Pembelajaran Interaktif. Jakarta : Maju Jaya Press

Rahayuningsih, E \& Dwiyanto, J. 2005. Pembelajaran di Laboratorium. Yogyakarta: Pusat Pendidikan Pengembangan UGM

Riwindikdo, H. 2009. Statistik Kesehatan. Yogyakarta: Mitra Cendikia Press

Shofari, B. 2004. PSRM1 Pengelolaan Sistem Rekam Medik. Semarang: PORMIKI

Sanjaya, W. 2008. Perencanaan dan Desain Sistem Pembelajaran. Jakarta: Kencana Prenada Media Group

Sukmadinata, NS. 2010. Pengembangan Kurikulum. Bandung : PT.Remaja Rosdakarya

Sugiyono. 2011. Metodologi Penelitian Kuantitatif, Kualitatif dan R\&D. Bandung : CV Alfabeta

Trianto. 2007. Model-Model Pembelajaran Inovatif Berorientasi Konstruktivistik. Jakarta: Prestasi Pustaka 
Yang, Ming-Ying, Manlai You, Fei- Chuan Chen. 2005. Competencies and Qualification for Industrial Design Jobs: Implication for Design Practice, Education, and Student Career Guidance. Elsevier Ltd.

Hartati, B. 2010. Pengembangan Alat Peraga Gaya Gesek untuk Meningkatkan Keterampilan Berpikir Kritis Siswa SMA. Dalam Jurnal Pendidikan Fisika Indonesia 6 (2000) 128132 ISSN: 1693:1246. Jawa Tengah: SMAN 2 Pekalongan

Kibrani, Budiyono dan Sutanto. 2012. Pengembangan Model Assesment For Learning (Afl) melalui Penilaian Teman Sejawat untuk Pembelajaran Matematika pada Pokok Bahasan Persamaan Garis Lurus di Madrasah Tsanawiyah Pondok Pesantren Modern Islam As salam Sukoharjo. Surakarta: PPs Universitas Sebelas Maret

Salirawati, Das. 2007. Media Kartu Sebagai Sarana Belajar Kimia Secara Mudah dalam http:// uny.ac.id/mediakartu-kimia diakses tanggal 19 April 2013 Jam 19.00 WIB

Supriatna. 2007. Pengaruh Media Pembelajaran Terhadap Motivasi dan Prestasi Belajar Siswa di SMP N 1 Lampung dalam http://repositoryusu.ac.id/tesis/media +motivasi + prestasi diakses tanggal 22 April 2013 Jam 08.00 WIB

Santyasa, I. W. 2007. Model-Model Pembelajaran Inovatif. Makalah. Disajikan dalam pelatihan tentang Penelitian Tindakan Kelas bagi GuruGuru SMA\&SMP di Nusa Penida tanggal 29 Juni s.d 1 Juli 2007
Sucita, T. Pengembangan Model Pembelajaran Praktikum Berbasis Software Komputer. Bandung: Universitas Pendidikan Indonesia

Suartama, I. K. 2010. Pengembangan Multimedia untuk Meningkatkan Kualitas Pembelajaran pada Mata Kuliah Media Pembelajaran. Dalam Jurnal Pendidikan dan Pengajaran, Jilid 43. Nomor 3, Oktober 2010 Hlm 253262. Universitas Pendidikan Ganesha

Witara, Dyah. 2008. Aplikasi Media Flash Untuk Meningkatkan Prestasi Siswa dalam http:// repository-usu.ac.id/media/prestasi diakses tanggal 18 April 2013 Jam 08.00 WIB

Wati, U. A. 2010. Pengembangan Multimedia Pembelajaran untuk Mata Kuliah Pembelajaran Terpadu. Dalam Jurnal Penelitian Ilmu Pendidikan Tahun 1 Volume 1 September 2010. Yogyakarta: UNY

Wirawan, I. M. A dan Ratnaya, I. G. 2011. Pengembangan Desain Pembelajaran Mobile Learning Management System pada Materi Pengenalan Komponen Jaringan. Dalam Jurnal Penelitian dan Pengembangan Pendidikan. Lembaga Pendidikan Undiksha 